\title{
Correlation of Gender, GPA and Multicultural to Emotional Intelligence Skill in STAD Cooperative Learning Multicultural Based
}

\author{
Ivan Th. J. Weismann ${ }^{1}$, Hengki Wijaya ${ }^{1, *}$, Helaluddin ${ }^{2}$ \\ ${ }^{1}$ Department of Christian Religious Education, Sekolah Tinggi Filsafat Jaffray Makassar, Indonesia \\ ${ }^{2}$ Department of Tarbiya and Teachers Training, Universitas Islam Negeri (UIN) Sultan Maulana Hasanuddin Banten, Indonesia
}

Received August 17, 2020; Revised October 18, 2020; Accepted October 24, 2020

\section{Cite This Paper in the following Citation Styles}

(a): [1] Ivan Th. J. Weismann, Hengki Wijaya, Helaluddin, "Correlation of Gender, GPA and Multicultural to Emotional Intelligence Skill in STAD Cooperative Learning Multicultural Based," Universal Journal of Educational Research, Vol. 8, No. 12, pp. 6561-6573, 2020. DOI: 10.13189/ujer.2020.081221.

(b): Ivan Th. J. Weismann, Hengki Wijaya, Helaluddin (2020). Correlation of Gender, GPA and Multicultural to Emotional Intelligence Skill in STAD Cooperative Learning Multicultural Based. Universal Journal of Educational Research, 8(12), 6561-6573. DOI: 10.13189/ujer.2020.081221.

Copyright $\mathrm{O} 2020$ by authors, all rights reserved. Authors agree that this article remains permanently open access under the terms of the Creative Commons Attribution License 4.0 International License

\begin{abstract}
This study aims to explore whether there is a relationship between gender, GPA, and multicultural students towards emotional intelligence in STAD cooperative learning in class. In this research, emotional intelligence indicators include self-introducing, self-control, motivation, empathy, and social skills. To achieve the objectives of the study, the researchers chose a quantitative approach using Statistical Package for the Social Sciences (SPSS) assistance. The participants were 70 students (26 male \& 44 female) from the Jaffray School of Theology in Makassar, Indonesia, who had diverse ethnic backgrounds. To analyze the data, researchers used the ANOVA statistical test. The results of data analysis show that gender differences do not determine: (1) emotional intelligence, (2) GP does not learn the increase in emotional intelligence, and (3) the relationship between ethnic backgrounds consisting of eleven tribes does not differ on emotional intelligence. Except for one indicator, namely, self-control is different among the eleven tribes. Gender differences and student GPA did not affect emotional intelligence. Student self-control differs from a student's response to diversity in the classroom and overcoming learning problems. This differs from the research on intellectual intelligence, which is influenced by GPA, gender, and multiculturalism.
\end{abstract}

Keywords Cooperative Learning, Emotional Intelligence, Gender, GPA, Multicultural

\section{Introduction}

The concept of emotional intelligence (EI) began to be introduced in various scientific literature around the 1990s [1]. EI's roots are rooted in David Wechsler's 1940 concept of the non-collective aspect of general Intelligence [2]. Emotional Intelligence evolved from an emphasis on leadership practices that reflected the use of several critical human skills [3].

Emotional intelligence is defined as the development of social behavior played by emotions and is very important for teachers, teaching, and students [4]. Dolev and Leshem added that this concept had highlighted a process of interdependence between aspects of cognition and emotions and the important role of emotions in thinking and making decisions [5]. This intelligence is characterized as the ability to identify, defend, control strength, communicate, make extraordinary decisions, overcome problems, and interact with other individuals in such a way as to make them successful [6]. In short, solving problems and making wise decisions using thoughts, feelings, logic, and intuition are part of what is called emotional intelligence [7], [8].

In general, emotional intelligence is a concept that is progressively discussed in social psychology [9]. 
However, this concept of intelligence has also penetrated the field of interdisciplinary studies, including in moral education for the past decades [10]. Educational psychology believes that to combine emotional intelligence is the goal that underlies the existence of teaching and learning, especially in universities [11] [12].

In the field of education, there has been a relatively high increase in the role of emotional intelligence in student success and the importance of their emotional adjustment in school [13]. Many authors argue that current community demands require additional skills in emotional awareness, decision making, social interaction, and conflict resolution as they enter adulthood [14]. Thus, it is not enough to be an intelligent and persistent student to achieve life success. Students also need to have another advantage that is not less important, namely the ability to understand and manage emotions [15].

Various studies indicate that emotional intelligence is essential given to students at every level of education. Damasino [12] states that emotions and learning are very carefully related to one another. That is, learning success does not only occur because of rational abilities but is also influenced by the development of emotional skills [13]. Nor [14] emphasizes that students have the potential to have interdisciplinary problems when their Emotional Intelligence fails to develop along with the development of cognitive intelligence. In other words, students with low emotional intelligence can increase the number of deviant behaviors.

In the context of higher education, there are still many campuses that traditionally only focus on rational and linguistic Intelligence without regard to other types of Intelligence [15]. Thus, universities should focus on developing the whole personality of students who develop intellectual, emotional, and social skills that can help achieve their future success [16]. Related to the role of Emotional Intelligence, Joshi [17] claims that Intelligence is more important for someone in achieving his goals compared to general intelligence.

Some studies on the relationship between EI and learning at the tertiary level have been carried out by researchers. High emotional intelligence is considered to contribute to the students' learning process [18] [19]. The same thing was also stated by researchers who said that social, and emotional learning was an empowering factor that was able to stimulate academic success and needed to be integrated into the tertiary curriculum [20] [21] [22].

Specifically, studies on learning with a primary focus on aspects of emotional intelligence have been conducted by researchers. Although EI is believed to be a scientific process, much literature shows that training and learning can contribute to students' overall professional and academic performance [23] [24] [25]. Some studies on EI and learning include the use of software/applications that are statistically proven to support student academic achievement, emotional intelligence, and attitudes towards the environment [26]. Emotional intelligence affects the reading skills of students, [27] and the importance of introducing emotional intelligence learning modules that can help students improve their negative behavior and attitudes [28].

One is conducted by applying multicultural-based STAD-type cooperative learning models to see students' social intelligence skills. STAD type cooperative learning model is a cooperative learning approach that emphasizes students' activities and interactions to motivate each other and help them master the subject matter to achieve maximum achievement. STAD has five principles, namely, (1) the principle of positive interdependence, (2) face to face promotion (face to face promotion interaction), (3) participation and communication (participation communication), (4) evaluation of group processes. If these principles can be well implemented, then this model will be useful in activating students that have an impact on improving student learning outcomes [29].

Arends [30] said that multicultural education is a teaching approach that aims to help students recognize and appreciate the diversity of cultural differences. In line with that, Mukhtar [31] stated that the educational approach and artistic approach could be used as instruments in building educational systems in a plural society. Zamroni [32] argues that multicultural education as a form of knowledge that is based on social justice, educational equality, and a dedication to provide a learning experience where all students can achieve optimal development.

Multicultural-based learning focuses on understanding and trying to live in a religious and cultural context, both individually and as a group, and not trapped in primordialism and the exclusion of narrow-based religious or cultural groups. The next emphasis will be put on understanding shared values and collaborative efforts to overcome common problems: crime, poverty, and underdevelopment and instill sympathy, appreciation, and empathy for adherents of different religions and cultures [33].

Pagalajar-Palomino et al. [34] concludes that it is essential to implement programs that develop emotional intelligence in adolescents in a multicultural context. Through the development of skills in emotional intelligence, a more humane and just society will be achieved and overcome many conflicts.

Schools play an important role in instilling multicultural values in students from an early age. If from the beginning, they already have the importance of togetherness, tolerance, love for peace, and respect for differences, these values will be reflected in their daily behavior because of their personality. If the younger generation successfully owns it, then the future life can be predicted to be relatively peaceful and full of respect, among others, can be realized. The multicultural-based STAD cooperative learning model is the answer.

From these studies, there are still very few researchers 
who associate emotional intelligence with multicultural approaches in higher education [35]. The inadequacy of studies on this topic in Indonesia makes this research very important [36]. For this reason, the authors are interested in exploring the effectiveness of STAD cooperative learning to improve students' Emotional Intelligence.

The formulations of the problem in this study are:

1. What is the correlation between sex and emotional intelligence skills of students?

2. What is the relationship between GPA and students' emotional intelligence skills?

3. What is the relationship between multicultural differences in students' emotional intelligence skills?

\section{Literature Review}

\subsection{Emotional Intelligence}

Emotional intelligence (EI) began to be discussed a lot by experts after the debate emerged that intelligence focused not only on the cognitive realm but also on other aspects. After the 20th century, emotional intelligence became the center of psychological study both in clinical practice and academia [37]. Emotional intelligence is rooted in the theory of multiple intelligences, which claims that human intelligence includes nine types [38]. The nine types of intelligence are linguistic, logic-mathematical, musical, interpersonal, intrapersonal, spatial, kinesthetic, naturalist, and existential. Furthermore, Goleman categorizes emotional intelligence as a form of integration between interpersonal intelligence and intrapersonal intelligence [39].

This intelligence is defined as the ability to feel and express emotions applied to facilitate thinking, understand and reason through their thoughts, and organize them in themselves and others [40]. Another definition is also put forward by Machera \& Machera [28] which states that emotional intelligence is related to productivity and performance, which can be measured and developed, and is a continuous change in improving human behavior.

\subsection{STAD Cooperative Learning}

One of the 21st-century skills that must be possessed by students is the ability to work together. It is confirmed by Sural, who classifies four skills in this era [41]. In the classification of ways of working, Sural divides it into two primary skills, namely communication skills and the skills of working together or teamwork.

The cooperative learning model has gained a place as a respected pedagogic in various countries. This postulate was stated by Baloche \& Brody who noted that the model had the potential to influence student achievement positively [42]. Besides, the cooperative model can also increase motivation for learning and intergroup relations and improve thinking and problem solving critically and creatively.

Cooperative learning is developed from the ideas of Vygotsky, Piaget, and Kohlberg, which emphasize that each individual and social setting is a powerful dynamic in the learning process. Students try to imitate real-life learning [43]. By combining teamwork and individual accountability, students try to gain knowledge and social skills. This cooperative strategy is a learning strategy that provides opportunities for students to work together in small groups with other individuals of various talents, academic abilities, and backgrounds in achieving common goals [44] [45].

Thus, the STAD cooperative learning model is a learning model where students learn in heterogeneous groups (levels of achievement, gender, culture, and Multicultural) consisting of 4-5 students. Learning activities begin with the delivery of learning objectives, delivery of material, group activities, quizzes, and group awards reflected in teamwork.

\subsection{Multicultural Learning}

Multicultural-based learning focuses on understanding and trying to live in a religious and cultural context, both individually and as a group, and not trapped in primordialism and the exclusion of narrow-based religious or cultural groups. Furthermore, the learning model emphasizes shared values and collaborative efforts to address common problems: crime, poverty, and underdevelopment. It will also instill sympathy, respect, and empathy for people of different religions and cultures [33].

The conception of multicultural education is often found in various literatures, and various notions are also seen. Still, two main forces influence or encourage the implementation of education, namely diversity and the value of justice. Moreover, it aims to prevent the threat of social disintegration caused by the negative impact of ethnic differences. Arends said that multicultural education is a teaching approach that seeks to help students recognize and appreciate the diversity of cultural difference [30]. Mukhtar argues that the educational approach and cultural approach can be used as an example in building an education system in a plural society [31].

\section{Research Methodology}

This section describes the research methods used so that the research process can run adequately and scientifically. This section describes (a) the research design used, (b) the participants involved, (c) data collection techniques, and (d) data analysis techniques.

\subsection{Research Design}

This type of research is quantitative research [46]. The research objective was to determine the effectiveness of 
applying multicultural-based learning models for improving emotional intelligence. This study found the relationship of respondents based on gender, multicultural culture, and the student cumulative achievement index on the improvement of emotional intelligence indicators. Statistical Package for the Social Sciences (SPSS) will process questionnaire data to produce data [47], [48]. Furthermore, the data explains the effect of learning models on student intelligence.

\subsection{Participants of the Study}

The research subjects are Jaffray School of Theology students in Makassar, consisting of various tribes that follow general psychology learning using multicultural-based STAD cooperative learning models. Researchers distributed questionnaires to 120 students, but only 70 students responded and returned them. The participants' demographics are grouped by gender, GPA, and ethnicity, as was shown in tables 1 to 3 below.

Table 1. Number of Respondents by Gender

\begin{tabular}{|c|c|c|}
\hline Gender & Respondents & Percentage \\
\hline Man & 26 & $37.10 \%$ \\
\hline Female & 44 & $62.90 \%$ \\
\hline
\end{tabular}

Table 1 shows the number of respondents based on gender. The research respondents consisted of 26 men and 44 women. The number of respondents was students who answered the emotional intelligence questionnaire in this study.

Table 2. Respondents Based on GPA

\begin{tabular}{|c|c|c|}
\hline Grade-point Average (GPA) & Amount & \% \\
\hline $2,0-2,49$ & 4 & 5.7 \\
\hline $2,5-2,99$ & 12 & 17.1 \\
\hline $3,0-3,49$ & 24 & 34.3 \\
\hline $3,5-4,0$ & 30 & 42.9 \\
\hline
\end{tabular}

Table 2 divides respondents based on GPA with GPA 2.0-4.0 intervals into four levels. Most respondents were 30, with a GPA interval of 3.35-4.0. The smallest number of respondents is in the GPA 2.0-2.49 interval, namely four respondents.

Table 3. Multicultural Respondents

\begin{tabular}{|c|c|c|}
\hline Origin & Respondents & Percentage \\
\hline Kalimantan & 17 & 24.3 \\
\hline Toraja & 21 & 30 \\
\hline Minahasa & 13 & 18.6 \\
\hline Mandar & 2 & 2.9 \\
\hline Jawa & 2 & 2.9 \\
\hline Batak/Sumatra & 1 & 1.14 \\
\hline Kupang/Alor & 6 & 8.6 \\
\hline Flores/Manggarai & 2 & 2.9 \\
\hline Bugis & 1 & 1.14 \\
\hline Ambon & 1 & 1.14 \\
\hline Papua & 4 & 5.7 \\
\hline
\end{tabular}

Table 3 describes the cultural background of the respondents. The number of respondents who answered the questionnaire was dominated by the Toraja, Kalimantan, and Minahasa ethnic groups. The smallest amount of respondents is the Ambonese, Bugis, and Batak ethnic groups.

This research measures the effectiveness of STAD-based multicultural learning models. The indicators of gender, GPA and multicultural aspect are the indicators (X) on emotional intelligence (Y). Based on gender, the number of female respondents is more than male respondents. Apart from the gender aspect, most of the respondent's ethnicity is Toraja, while the least respondent's ethnicity is Bugis, Ambon, and Batak. The GPA shows that 54 respondents have a GPA higher than 3.0 while the other 16 respondents have a GPA below 3.00.

\subsection{Data Collection}

Data collection in this study used questionnaires[49] by using multicultural type STAD based learning models [50] [51]. The questionnaire used in this study consisted of 50 question items by giving five alternative answer choices, namely: (a) very suitable, (b) appropriate, (c) doubtful, (d) inappropriate, and (e) very unsuitable. The results of the questionnaire were processed statistically using SPSS 22 Software [52].

\subsection{Data Analysis Procedure}

Before the questionnaire is used, the researcher must perform a validation test to determine the instrument's validity. The instrument is declared valid if it meets the criteria of $r$ count $>r$ table based on a significant test of 0.05 , meaning that the items are valid [46] [53]. In addition to the validity test, researchers also tested the reliability of the research instruments used. The reliability test with Cronbach's Alpha explains that if alpha $>0.90$, then the reliability level is in a perfect category. Furthermore, if alpha is between $0.70-0.90$, then the reliability level is in the high category. Also, if alpha is $0.50-0.70$, then the reliability level is in the moderate category; while alpha is $<0.50$, then the level of reliability is in a low category. In other words, if alpha is small, chances are one or more items that are not reliable [54], [56].

In addition to the two types of tests above, researchers also used a test of homogeneity of variance to determine whether the respondent has the same treatment to obtain uniformity of variance. The Levene test has since been shown to have an increased level of significance based on the F-distribution and test hypotheses other than the variance [57]. If the test of homogeneity of variances meets the identical variance hypothesis, then the next test, the ANOVA statistical test [58], [59], [60] is conducted to explain gender relations, student GPA, multicultural indicators of student intelligence (self-introduction, 
self-control, motivation, empathy, and social skills) [50].

\section{Results}

\subsection{Validity \& Reliability Test}

Hasil uji validitas terhadap angket penelitian tersebut ditemukan ada enam item soal dari 50 soal yang dinyatakan invalid because of the value of $r$ count $<r$ table (0.279) based on a significant test of 0.05 . Furthermore, Cronbach's Alpha Reliability test shows a Cronbach Alpha value of 0.895 , which shows that the fifty statements of reliability are high because they are in the range of 0.70-0.90.

\subsection{Gender \& Emotional Intelligence Statistics}

Table 4 shows the average of each emotional intelligence skill between men and women with a $95 \%$ confidence level. Analysis of table 5 shows whether male and female populations have the same variance, that is, get the same treatment in developing emotional intelligence skills.

Hypothesis:

$\mathrm{H} 0=$ Both population variances are identical

$\mathrm{H} 1=$ The two population variances are not identical.

Basic decision making:

If the probability is $>0.05$, then $\mathrm{H} 0$ is accepted.

If the probability is $<0.05$, then $\mathrm{H} 0$ is rejected.

It can be seen that the calculated Levene Test is all probability values for each emotional intelligence skill > 0.05 , then $\mathrm{H} 0$ is accepted, or the two population variances are the same. Thus, the assumption of similarity of variance for the Anova test has been fulfilled.

Table 4. Relationship between Gender and EI

\begin{tabular}{|c|c|c|c|}
\hline \multicolumn{2}{|c|}{ EI and Gender Indicators } & N & Mean \\
\hline \multirow{3}{*}{ Knowing Self } & Man & 26 & 36,2692 \\
\cline { 2 - 4 } & Female & 44 & 35,9318 \\
\cline { 2 - 4 } & Total & 70 & 36,0571 \\
\hline \multirow{4}{*}{ Self-control } & Man & 26 & 34,2308 \\
\cline { 2 - 4 } & Female & 44 & 33,7273 \\
\cline { 2 - 4 } & Total & 70 & 33,9143 \\
\hline \multirow{4}{*}{ Motivation } & Man & 26 & 37,3077 \\
\cline { 2 - 4 } & Female & 44 & 37,4091 \\
\cline { 2 - 4 } & Total & 70 & 37,3714 \\
\hline \multirow{3}{*}{ Empathy } & Man & 26 & 35,4231 \\
\cline { 2 - 4 } & Female & 44 & 35,2727 \\
\cline { 2 - 4 } & Total & 70 & 35,3286 \\
\hline \multirow{3}{*}{ Social skill } & Man & 26 & 35,3846 \\
\cline { 2 - 4 } & Female & 44 & 34,2500 \\
\cline { 2 - 4 } & Total & 70 & 34,6714 \\
\hline
\end{tabular}

Table 5. Test of Homogeneity of Variances

\begin{tabular}{|c|c|c|c|c|}
\hline EI Indicator & $\begin{array}{c}\text { Levene } \\
\text { Statistic }\end{array}$ & df1 & df2 & Sig. \\
\hline Knowing Self &, 811 & 1 & 68 &, 371 \\
\hline Self-control &, 032 & 1 & 68 &, 859 \\
\hline Motivation &, 160 & 1 & 68 &, 690 \\
\hline Empathy & 1,838 & 1 & 68 &, 180 \\
\hline Social Skills &, 166 & 1 & 68 &, 685 \\
\hline
\end{tabular}

Table 6. ANOVA Test between Gender and EI

\begin{tabular}{|c|c|c|c|c|c|c|}
\hline \multicolumn{2}{|c|}{ EI Indicator } & Sum of Squares & df & Mean Square & $\mathbf{F}$ & Sig. \\
\hline \multirow{3}{*}{ Knowing self } & Between Groups & 1,861 & 1 & 1,861 &, 117 &, 734 \\
\hline & Within Groups & 1083,911 & 68 & 15,940 & & \\
\hline & Total & 1085,771 & 69 & & & \\
\hline \multirow{3}{*}{ Self-control } & Between Groups & 4,143 & 1 & 4,143 &, 175 & ,677 \\
\hline & Within Groups & 1609,343 & 68 & 23,667 & & \\
\hline & Total & 1613,486 & 69 & & & \\
\hline \multirow{3}{*}{ Motivation } & Between Groups & , 168 & 1 & , 168 &, 006 & ,939 \\
\hline & Within Groups & 1946,175 & 68 & 28,620 & & \\
\hline & Total & 1946,343 & 69 & & & \\
\hline \multirow{3}{*}{ Empathy } & Between Groups & 369 & 1 & ,369 &, 021 &, 885 \\
\hline & Within Groups & 1189,073 & 68 & 17,486 & & \\
\hline & Total & 1189,443 & 69 & & & \\
\hline \multirow{3}{*}{ Social skill } & Between Groups & 21,039 & 1 & 21,039 & ,796 & ,375 \\
\hline & Within Groups & 1796,404 & 68 & 26,418 & & \\
\hline & Total & 1817,443 & 69 & & & \\
\hline
\end{tabular}


After the two populations prove the same, the next step is to test whether the two sample populations have the same mean (mean) for each emotional intelligence skill.

Hypothesis:

$\mathrm{H} 0=$ Both population averages are identical.

$\mathrm{H} 1=$ The two population averages are not identical.

Basic decision making:

If the $\mathrm{F}$ statistic is counted $>\mathrm{F}$ table, then $\mathrm{H} 0$ is rejected.

If the $\mathrm{F}$ statistic is counted $<\mathrm{F}$ table, then $\mathrm{H} 0$ is accepted.

The significance level of alpha is $5 \%$, numerators are 2-1 $=1$, denumerators are 70-2 $=68$.

From table F, a figure of 3,98 is obtained. Since F arithmetic located in the H0 region is accepted, it can be concluded that the two groups' average does not differ in each emotional intelligence skill. In Table 6, F's statistical value is smaller than in the $\mathrm{F}$ table, so the decision $\mathrm{H} 0$ is accepted.

The results of the decision show that probability $>0.05$, then $\mathrm{H} 0$ is accepted, or the average of the two populations is identical or not different in terms of emotional intelligence skills. Thus any gender differences provide emotional intelligence skills that are not different between men and women. Thus emotional intelligence skills are not determined by gender differences. Lecturers should not distinguish between emotional Intelligence based on gender differences.

\subsection{GPA and EI Statistics}

Table 7 shows the average of each emotional intelligence skill between the GPA level and the 95\% confidence level. The analysis of table 8 examines whether the GPA level/class population has the same variants, namely getting the same treatment in developing emotional intelligence skills.

Hypothesis:

$\mathrm{H} 0=$ The four population variances are identical

$\mathrm{H} 1=$ The four population variances are not identical

Basic Decision Making:

If the probability is $>0.05$, then $\mathrm{H} 0$ is accepted

If the probability is $<0.05$, then $\mathrm{H} 0$ is rejected

Decision results show that the calculated Levene Test is all probability values for each emotional intelligence skill $>$ 0.05 , then $\mathrm{HO}$ is accepted, or all four population variances are the same. Therefore, the assumption of variance similarity for the Anova test has been fulfilled.

Table 7. Relationship between GPA and EI

\begin{tabular}{|c|c|c|c|}
\hline \multicolumn{2}{|c|}{$\begin{array}{c}\text { EI indicator } \\
\text { And GPA }\end{array}$} & $\mathbf{N}$ & Mean \\
\hline \multirow{5}{*}{ Knowing Self } & $2,00-2,49$ & 4 & 38,2500 \\
\hline & $2,5-2,99$ & 12 & 34,3333 \\
\hline & $3,0-3,49$ & 24 & 36,3750 \\
\hline & $3,5-4,0$ & 30 & 36,2000 \\
\hline & Total & 70 & 36,0571 \\
\hline \multirow{5}{*}{ Self-control } & $2,00-2,49$ & 4 & 33,5000 \\
\hline & $2,5-2,99$ & 12 & 33,7500 \\
\hline & $3,0-3,49$ & 24 & 33,0000 \\
\hline & $3,5-4,0$ & 30 & 34,7667 \\
\hline & Total & 70 & 33,9143 \\
\hline \multirow{5}{*}{ Motivation } & $2,00-2,49$ & 4 & 39,0000 \\
\hline & $2,5-2,99$ & 12 & 33,9167 \\
\hline & $3,0-3,49$ & 24 & 37,0833 \\
\hline & $3,5-4,0$ & 30 & 38,7667 \\
\hline & Total & 70 & 37,3714 \\
\hline \multirow{5}{*}{ Empathy } & $2,00-2,49$ & 4 & 35,2500 \\
\hline & $2,5-2,99$ & 12 & 34,6667 \\
\hline & $3,0-3,49$ & 24 & 35,4167 \\
\hline & $3,5-4,0$ & 30 & 35,5333 \\
\hline & Total & 70 & 35,3286 \\
\hline \multirow{5}{*}{ Social skill } & $2,00-2,49$ & 4 & 33,7500 \\
\hline & $2,5-2,99$ & 12 & 36,0000 \\
\hline & $3,0-3,49$ & 24 & 34,5000 \\
\hline & $3,5-4,0$ & 30 & 34,4000 \\
\hline & Total & 70 & 34,6714 \\
\hline
\end{tabular}

Table 8. Test of Homogeneity of Variances

\begin{tabular}{|c|c|c|c|c|}
\hline EI Indicator & Levene Statistic & df1 & df2 & Sig. \\
\hline Knowing Self &, 920 & 3 & 66 &, 436 \\
\hline Self-control &, 037 & 3 & 66 &, 991 \\
\hline Motivation &, 532 & 3 & 66 &, 662 \\
\hline Empathy &, 390 & 3 & 66 &, 761 \\
\hline Social Skills & 2,424 & 3 & 66 &, 073 \\
\hline
\end{tabular}


Table 9. ANOVA Test between GPA and EI

\begin{tabular}{|c|c|c|c|c|c|c|}
\hline \multicolumn{2}{|c|}{ EI Indicator } & Sum of Squares & df & Mean Square & $\mathbf{F}$ & Sig. \\
\hline \multirow{3}{*}{ Knowing self } & Between Groups & 57,930 & 3 & 19,310 & 1,240 &, 302 \\
\hline & Within Groups & 1027,842 & 66 & 15,573 & & \\
\hline & Total & 1085,771 & 69 & & & \\
\hline \multirow{3}{*}{ Self-control } & Between Groups & 42,869 & 3 & 14,290 & 600 &, 617 \\
\hline & Within Groups & 1570,617 & 66 & 23,797 & & \\
\hline & Total & 1613,486 & 69 & & & \\
\hline \multirow{3}{*}{ Motivation } & Between Groups & 214,226 & 3 & 71,409 & 2,721 &, 051 \\
\hline & Within Groups & 1732,117 & 66 & 26,244 & & \\
\hline & Total & 1946,343 & 69 & & & \\
\hline \multirow{3}{*}{ Empathy } & Between Groups & 6,726 & 3 & 2,242 &, 125 &, 945 \\
\hline & Within Groups & 1182,717 & 66 & 17,920 & & \\
\hline & Total & 1189,443 & 69 & & & \\
\hline \multirow{3}{*}{ Social skill } & Between Groups & 27,493 & 3 & 9,164 &, 338 &, 798 \\
\hline & Within Groups & 1789,950 & 66 & 27,120 & & \\
\hline & Total & 1817,443 & 69 & & & \\
\hline
\end{tabular}

After the four are proven to be the same, the next step is to test whether the four GPA levels have the same mean (mean) for each emotional intelligence skill.

Hypothesis:

$\mathrm{H} 0=$ All four population means are identical

$\mathrm{H} 1=$ All four population means are not identical

Basic Decision Making:

If the F statistic is counted $>\mathrm{F}$ table statistics, then $\mathrm{H} 0$ is rejected

If the F statistic is calculated $<$ Statistics $\mathrm{F}$ table, then $\mathrm{H} 0$ is accepted

The significance level of alpha is $5 \%$, numerator is $4-1=$ 3 , an enumerator is $70-4=66$. From table $\mathrm{F}$, the number is 2,75. In Table 9, F's statistical value is smaller than in the F table, so the decision $\mathrm{H} 0$ is accepted. Table 9 shows that the motivation indicator shows a high $F$ value (2.721) but not greater than 2.75 so that $\mathrm{H} 0$ is accepted. Since F arithmetic located in the $\mathrm{H} 0$ area is accepted, it can be concluded that the four GPA level groups average does not differ in each emotional intelligence skill. Decision Seen that the probability $>0.05$, then $\mathrm{H} 0$ is accepted, or the average of the four populations is identical or not different in terms of emotional intelligence skills.

Students who have low and high GPAs have no difference in emotional intelligence skills. Lecturers need to understand that one's GPA does not determine the increase in the emotional intelligence of students. GPA is correlated with IQ, but not with EI.

\subsection{Multicultural and EI Statistics}

Table 10 shows the average of each emotional intelligence skills between each tribe with a 95\% confidence level. Analysis of table 11 examines whether tribal populations have the same variance, that is, get the same treatment in developing emotional intelligence skills.

Hypothesis:

$\mathrm{H} 0=$ eleven population variances are identical

$\mathrm{H} 1=$ eleven population variances are not identical

Basic decision making:

If the probability is $>0.05$, then $\mathrm{H} 0$ is accepted

If the probability is $<0.05$, then $\mathrm{H} 0$ is rejected

The decision shows that the Levene Test count is all probability values for each emotional intelligence skill $>$ 0.05 , then $\mathrm{H} 0$ is accepted, or the eleven population variances are the same. Thus, the assumption of similarity of variance for the Anova test has been fulfilled. 
Table 10. Relationship between Multicultural dan EI

\begin{tabular}{|c|c|c|c|}
\hline \multicolumn{2}{|c|}{ EI Indicator and Multicultural } & $\mathbf{N}$ & Mean \\
\hline \multirow{12}{*}{ Knowing self } & Kalimantan & 17 & 35,3529 \\
\hline & Toraja & 21 & 35,4762 \\
\hline & Minahasa & 13 & 35,7692 \\
\hline & Mandar & 2 & 41,0000 \\
\hline & Jawa & 2 & 38,0000 \\
\hline & Batak & 1 & 37,0000 \\
\hline & Kupang & 5 & 36,4000 \\
\hline & Flores & 3 & 37,0000 \\
\hline & Bugis & 1 & 32,0000 \\
\hline & Ambon & 1 & 39,0000 \\
\hline & Papua & 4 & 38,5000 \\
\hline & Total & 70 & 36,0571 \\
\hline \multirow{12}{*}{ Self-control } & Kalimantan & 17 & 33,2353 \\
\hline & Toraja & 21 & 32,4762 \\
\hline & Minahasa & 13 & 33,6923 \\
\hline & Mandar & 2 & 37,5000 \\
\hline & Jawa & 2 & 43,5000 \\
\hline & Batak & 1 & 31,0000 \\
\hline & Kupang & 5 & 37,2000 \\
\hline & Flores & 3 & 34,6667 \\
\hline & Bugis & 1 & 27,0000 \\
\hline & Ambon & 1 & 40,0000 \\
\hline & Papua & 4 & 34,7500 \\
\hline & Total & 70 & 33,9143 \\
\hline \multirow{12}{*}{ Motivation } & Kalimantan & 17 & 36,2941 \\
\hline & Toraja & 21 & 36,6190 \\
\hline & Minahasa & 13 & 38,5385 \\
\hline & Mandar & 2 & 43,0000 \\
\hline & Jawa & 2 & 36,5000 \\
\hline & Batak & 1 & 35,0000 \\
\hline & Kupang & 5 & 38,6000 \\
\hline & Flores & 3 & 37,6667 \\
\hline & Bugis & 1 & 36,0000 \\
\hline & Ambon & 1 & 38,0000 \\
\hline & Papua & 4 & 38,7500 \\
\hline & Total & 70 & 37,3714 \\
\hline \multirow{12}{*}{ Empathy } & Kalimantan & 17 & 34,2941 \\
\hline & Toraja & 21 & 35,5238 \\
\hline & Minahasa & 13 & 35,0000 \\
\hline & Mandar & 2 & 37,5000 \\
\hline & Jawa & 2 & 40,5000 \\
\hline & Batak & 1 & 36,0000 \\
\hline & Kupang & 5 & 34,0000 \\
\hline & Flores & 3 & 37,0000 \\
\hline & Bugis & 1 & 34,0000 \\
\hline & Ambon & 1 & 33,0000 \\
\hline & Papua & 4 & 37,2500 \\
\hline & Total & 70 & 35,3286 \\
\hline
\end{tabular}




\begin{tabular}{|c|c|c|c|}
\hline \multirow{12}{*}{ Social skill } & Kalimantan & 17 & 33,7059 \\
\hline & Toraja & 21 & 33,6667 \\
\hline & Minahasa & 13 & 35,9231 \\
\hline & Mandar & 2 & 36,0000 \\
\hline & Jawa & 2 & 40,0000 \\
\hline & Batak & 1 & 38,0000 \\
\hline & Kupang & 5 & 33,2000 \\
\hline & Flores & 3 & 37,0000 \\
\hline & Bugis & 1 & 30,0000 \\
\hline & Ambon & 1 & 34,0000 \\
\hline & Papua & 4 & 37,2500 \\
\hline & Total & 70 & 34,6714 \\
\hline
\end{tabular}

Table 11. Test of Homogeneity of Variances

\begin{tabular}{|c|c|c|c|c|}
\hline EI Indicator & Levene Statistic & df1 & df2 & Sig. \\
\hline Knowing self &, $870^{\mathrm{a}}$ & 7 & 59 &, 535 \\
\hline Self-control & $1,959^{\mathrm{b}}$ & 7 & 59 & ,076 \\
\hline Motivation &, $969^{\mathrm{c}}$ & 7 & 59 & ,462 \\
\hline Empathy & $1,127^{\mathrm{d}}$ & 7 & 59 & ,359 \\
\hline Social skills & $2,114^{\mathrm{e}}$ & 7 & 59 &, 056 \\
\hline
\end{tabular}

Table 12. ANOVA Test between Multicultural and EI

\begin{tabular}{|c|c|c|c|c|c|c|}
\hline \multicolumn{2}{|c|}{ EI Indicator } & \multirow{2}{*}{$\begin{array}{c}\text { Sum of Squares } \\
126,143\end{array}$} & \multirow{2}{*}{$\begin{array}{l}\mathbf{d f} \\
10\end{array}$} & \multirow{2}{*}{$\begin{array}{c}\text { Mean Square } \\
12,614 \\
\end{array}$} & \multirow{2}{*}{$\begin{array}{c}\mathbf{F} \\
, 776 \\
\end{array}$} & \multirow{2}{*}{$\begin{array}{l}\text { Sig. } \\
, 652 \\
\end{array}$} \\
\hline \multirow{3}{*}{ Knowing self } & Between Groups & & & & & \\
\hline & Within Groups & 959,628 & 59 & 16,265 & & \\
\hline & Total & 1085,771 & 69 & & & \\
\hline \multirow{3}{*}{ Self-control } & Between Groups & 413,203 & 10 & 41,320 & 2,031 &, 046 \\
\hline & Within Groups & 1200,283 & 59 & 20,344 & & \\
\hline & Total & 1613,486 & 69 & & & \\
\hline \multirow{3}{*}{ Motivation } & Between Groups & 137,514 & 10 & 13,751 & ,449 & ,916 \\
\hline & Within Groups & 1808,829 & 59 & 30,658 & & \\
\hline & Total & 1946,343 & 69 & & & \\
\hline \multirow{3}{*}{ Empathy } & Between Groups & 122,925 & 10 & 12,293 & 680 &, 738 \\
\hline & Within Groups & 1066,518 & 59 & 18,077 & & \\
\hline & Total & 1189,443 & 69 & & & \\
\hline \multirow{3}{*}{ Social skill } & Between Groups & 204,774 & 10 & 20,477 & ,749 & ,676 \\
\hline & Within Groups & 1612,669 & 59 & 27,333 & & \\
\hline & Total & 1817,443 & 69 & & & \\
\hline
\end{tabular}

After the eleven populations prove the same, the next step is to test whether the eleven sample populations (11 tribes) have the same mean (Mean) for each emotional intelligence skill.

Hypothesis:

$\mathrm{H} 0=$ eleven population mean are identical

$\mathrm{H} 1=$ eleven population mean is not identical

Basic decision making:

If the $\mathrm{F}$ statistic is counted $>\mathrm{F}$ table statistics, then $\mathrm{H} 0$ is rejected

If the F statistic is calculated $<$ Statistics F table, then HO is accepted

The significance level of alpha is $5 \%$, numerator is $11-1$ $=10$, an enumerator is $70-11=59$.

From table F, we get 1,99. Since F arithmetic located in the $\mathrm{H} 0$ area is accepted, it can be concluded that the multicultural level groups average does not differ in each emotional intelligence skill. Except for self-control skills, $\mathrm{F}$ counts located in the $\mathrm{H} 0$ area are rejected. The decision 
shows that probability $>0.05, \mathrm{H} 0$ is accepted, or the average of eleven populations is identical or not different in terms of emotional intelligence skills, except for self-control indicator. Table 12 shows that the $\mathrm{F}$ count of self-control skills (2.031) is greater than Table F (1.99), so the decision is Ho is rejected, or the average eleven populations are not identical or different in self-control skills.

Self-control is related to one's character. Fallah et al. argued that character building must carry out many actions with patience and persistence in controlling feelings that produce negative dimensions and strengthen feelings that produce positive ethics [61]. Someone who controls their feelings will produce correct ethical training. Faye et al. showed $70 \%$ have a self-assessment of poor emotional Intelligence. However, self-control is associated with good social relationships with others [62]. The multicultural-based STAD cooperative learning model improves emotional intelligence skills, behavior change, and character [63], [64]. Indicators of self-introduction, self-control [50], motivation [65], empathy [66], social skill [67] a must-have for students to improve their emotional intelligence skills.

\section{Discussion}

The results showed that students' gender relationships did not differ significantly between men and women in the increase in emotional intelligence. Previous research by Sutarso et al. [68] examined the relationship between gender and emotional intelligence in 138 students. Emotional intelligence is measured by a score on the compassion/empathy scale, self-control, and attunement of the instrument developed by Baggert et al. [69]. In this study, men and women differed significantly in compassion/empathy and self-awareness/self-control [68]. Previous research has reported that women tend to show more compassion and empathy than men [68], [70]. The relationship between emotional intelligence, communication effectiveness, and job satisfaction shows that women have a positive relationship with job satisfaction [71]. Research in soccer shows that most of the female soccer players in the study were androgynous, and their levels of emotional intelligence were significantly higher than that of other participants [72]. Sutarso et al. reported that gender differences occurred in terms of intensity of emotional experiences, empathy, body image and self-esteem, aggressive and social feelings, monitoring, copying, human relationships, emotional development, parenting and family support, and depression [68], [70], [73]. In leadership research on gender and emotional intelligence, no significant differences $(p>0.05)$ were found in the transformational leadership scores for male and female managers [74]. Significant differences between men and women in emotional intelligence can occur when levels of stress are different, and decision-making in acts of compassion and empathy. Another thing in the indicators of emotional intelligence does not differ between men and women in this study.

Other indicators, such as GPA, show that there is no difference in the level of GPA that affects emotional intelligence. Thus, it is clear that emotional intelligence does not depend on a person's intellectual level, but the decision to behave that will influence his actions. If there is no difference in the level of emotional intelligence due to GPA, then emotional intelligence can contribute to an increase in GPA. Reiff et al. [73] explained students could learn to develop and improve effective factors that may be related to academic and academic success (GPA). The learning process and emotional intelligence can be put into practice to be more effective. The aim is to prepare students to keep up with the demands of colleges and job vacancies. Sutarso et al. [68] supports this study that both GPA and gender do not significantly affect emotional intelligence. Hen and Goroshit concluded that no differences were found in indicators of GPA in students with Learning Disabilities (LD) and without LD [75]. Thus, this study proves the correctness of the theory that differences in the level of GPA do not have a gap in contributing to increased emotional intelligence.

Multicultural relationships (students with different cultural backgrounds) do not differ from one another except that self-control indicators make a distinct contribution to emotional intelligence. Tapia's research [76] yielded four factors of empathy, utilization of feelings, handling relationships, and self-control. This study's results indicate that there are differences in terms of self-control, which are influenced by cultural differences. Hystad et al. [77] reported no difference in total EQ scores, but higher scores on US students' self-control than Norwegian students. Although the sample (i.e., students vs. seafarers) is different, it might indicate EQ's self-control aspect. It restrains emotions and refrains from impulsive, emotional expression - may be more typical for Cluster North Europe and Asia, compared to Cluster North America. The research of Johnsen et al. [78] found higher scores on indicators of the utilization of emotions, handling relationships, and self-control. The study also found a negative correlation between age and scores on self-control indicators. These cross-cultural differences may have implications for interpersonal relationships. Thus, the interpersonal relationship between students with multicultural backgrounds requires adjustment and acceptance of different cultures in the boarding school community.

However, Crowne's [79] found that cultural exposure in all forms impacted cultural intelligence, while it had no impact on emotional intelligence. Also, Chrobot-Mason and Leslie [80] in research require multicultural competence, and emotional intelligence to deal with 
diversity. With this statement, further research recommendations need to look at the relationship between multicultural intelligence, multicultural competence, and emotional intelligence.

\section{Conclusions}

Emotional intelligence is an essential aspect of today's educational discourse. For this reason, this research was conducted to determine whether there was a correlation between sex, gender, and multicultural aspects of students' emotional Intelligence. First, the results of the study showed that the two populations (male \& female) were expressed identically differently in terms of emotional intelligence. That is, gender differences do not determine emotional intelligence. Second, the results of data analysis showed that the IPK group's empathy was expressed no differently in each emotional intelligence (five types of emotional Intelligence). In other words, students with low or high GPA have no difference in emotional intelligence. From these results, it can be established that the GPA does not determine the increase in emotional intelligence. Different from the two points above, the different outcomes are shown by the results of a debt test, which states that 11 ethnic students are not identical or different in emotional skills. That difference is proven by one indicator of emotional intelligence, namely the self-control ability of students.

\section{REFERENCES}

[1] P. Salovey and J. D. Mayer, "Emotional Intelligence," Imagination, Cognition and Personality, vol. 9, no. 3, pp. 185-211, 1990. doi: https://doi.org/10.2190/DUGG-P24E-5 2WK-6CDG.

[2] S. Nair and N. Srivastava, "Emotional Intelligence and Managerial Effectiveness: Role of Rational Emotive Behaviours," Indian Journal of Industrial Relations, vol. 46, no. 2, 2012.

[3] N. Broughton, "The Evolution of Emotional Intelligence," International Journal of Business and Social Sciences, vol. 8, no. 6, pp. 6-15, 2017.

[4] R. Gilar-Corbi, T. Pozo-Rico, M. L. Pertegal-Felices, and B. Sanchez, "Emotional Intelligence Training Intervention among Trainee Teachers: A Quasi-experimental Study," Psicologia: Reflexe Critica, vol. 31, no. 33, pp. 1-13, 2018, https://doi.org/httpa://doi.org/10.1186/s41155-018-0112-1

[5] N. Dolev and S. Leshem, "Teachers' Emotional Intelligence: The Impact of Training," International Journal of Emotional Education, vol. 8, no. 1, pp. 75-94, 2016.

[6] M. K. Stone, A. L. Jensen, J. M. Freedman, and M. S. Rideout, Self-science: The Emotional Intelligence Curriculum. San Mateo: 6Seconds, 1998.

[7] J. D. Mayer and P. Salovey, "What is Emotional
Intelligence?," in Emotonal Development and Emotional Intelligence: Educational implications, P. Salovey and D. J. Sluyter, Eds. New York: Basic Book, Inc, 1997, pp. 3-34.

[8] M. A. Brackett, S. E. Rivers, and P. Salovey, "Emotional Intelligence: Implications for Personal, Social, Academic, and Workplace Success," Social and Personality Psychology Compass, vol. 5, no. 1, pp. 88-103, 2011, https://doi.org/10.1111/j.1751-9004.2010.00334.x.

[9] N. Humphrey, A. Curran, E. Morris, and K. Woods, "Emotional Intelligence and Education: A Critical Review," Educational Psychoogy, vol. 27, no. 2, pp. 235-254, 2007, https://doi.org/10.1080/01443410601066735.

[10] T. E. Romarsz, J. H. Kantor, and M. J. Ellias, "Implementation and Evaluation of Urban School-wide Social-emotional Learning Programs," Evaluation andProgram Planning, vol. 27, pp. 89-103, 2004.

[11] C. Maccann, Y. Jiang, L. E. R. Brown, K. S. Double, M. Bucich, and A. Minbashian, "Emotional Intelligence Predicts Academic Performance: A Meta-Analysis," Psychological Bulletin, vol. 146, no. 2, pp. 150-186, 2020.

[12] A. Damasino, Descartes' Error: Emotion, Reason, and The Human Brain. New York: Putnam's, 1994.

[13] H. Hopfl and S. Linstead, "Learning to Feel and Feeling to Learn: Emotion and Learning in Organisations," Management Learning, vol. 28, pp. 5-12, 1997.

[14] N. A. K. M. Nor, Z. Ismail, and Y. M. Yusof, "The Relationship between Emotional Intelligence and Mathematical Competency among Secondary School Students," Journal on Mathematics Eduation., vol. 7, no. 2, pp. 91-100, 2016.

[15] S. Z. Malik and S. Shahid, "Effect of Emotional Intelligence on Academic Performance among Business Students in Pakistan," Bulletin of Education and Research, vol. 38, no. 1, pp. 197-208, 2016.

[16] C. R. Seal, S. E. Naumann, A. Scott, and J. Poyce-Davis, "Social Emotional Development: A New Model of Learning in Higher Education," Research in Higher Education, vol. 10, no. 1, pp. 1-13, 2011.

[17] V. Joshi, K. Srivastava, and A. Raychaudhuri, "A Descriptive Study of Emotional Intelligence in Graduate Professional Education," Research in Higher Eduation, vol. 44, no. 6, pp. 615-639, 2012.

[18] H. Svetlana, Emotional Intelligence and Academic Achievement. California: Pepperdine University, 2007.

[19] A. Yahaya et al., "The impact of Emotional Intelligence Element on Academic Achievement," Archive Des Sciences, vol. 65 , no. 4, pp. 2-16, 2012.

[20] J. E. Zins, M. J. Elias, M. T. Greenberg, and H. J. Weissberg, "Promotion of Social and Emotional Competence in Children," in Preventing School Problems-Promoting School Success: Strategies and Programs that Work, K. M. Minke and G. C. Bear, Eds. Bethesda: National Association of School Psychologists, 2004, pp. 71-79.

[21] J. D. A. Parker, J. M. Duffy, L. M. Wood, B. J. Bond, and M. J. Hogan, "Academic Success and Emotional Intelligence: Predicting The Successful Transition from High School to University," Journal of The First-Year Experience, vol. 17, no. 1, pp. 1-12, 2005. 
[22] M. J. Elias and J. Arnold, The Educator's Guide to Emotional Intelligence and Academic Success. Thousand Osaka: Corwin Press, 2006.

[23] W. Chan, "Emotional Intelligence and Component of Burnout among Chinese Secondary School Teachers in Hongkong.," Teaching and Teacher Education, vol. 22, pp. 1042-1054, 2006

[24] N. Clarke, "The Impact of a Training Programme Designed to Target The Emotional Intelligence Abilities of Project Managers," International Journal of Project Management, vol. 28, pp. 461-468, 2010.

[25] M. Hen and A. Sharabi-Nov, "Teaching The Teachers: Emotional Intelligence Training for Teachers," Teaching Education, vol. 25, no. 4, pp. 37-41, 2014, doi:10.1177/0022219412439325.

[26] O. Ercan, E. Ural, and S. Kose, "The Effect of Web Assisted Learning with Emotional Intelligence Content on Students' Information about Energy Saving, Attitudes towards Environment and Emotional Intelligence," Science Education Inernational., vol. 28, no. 1, pp. 78-94, 2017.

[27] M. R. Ebrahimi, H. Khoshsima, and E. Zare-Behtash, "The Impacts of Enhancing Emotional intelligence on The Development of Reading Skill," International Journal of Instruction, vol. 11, no. 3, pp. 573-586, 2018.

[28] R. P Machera and P. C Machera, "Emotional Intelligence (EI) A Therapy for Higher Education Students," Universal Journal of Educational Research, vol. 5, no. 3, pp. 461-471, 2017, doi:10.13189/ujer.2017.050318.

[29] S. Esminarto and K. Anam, "Implementasi Model STAD dalam Meningkatkan Hasil Belajar Siswa," BRILIANT: Jurnal Riset dan Konseptual, vol. 1, no. November, pp. 1623,2016

[30] R. Arends, Learning to Teach. Boston: McGraw Hills, 2001.

[31] S. A. Mukhtar, "Multikulturalisme dan Pendidikan Multikultural dalam Era Otonomi Daerah," Mimbar Pendidikan, vol. 4, no. XXIII, 2004.

[32] Z. Zamroni, Pendidikan Demokrasi pada Masyarakat Multikultural. Jakarta: Gavin Kalam Utama, 2011.

[33] M. Ali, Teologi Pluralis-Multikultural: Menghargai Kemajemukan \& Menjalin Kebersamaan. Jakarta: Kompas, 2003.

[34] M. C. Pegalajar-Palomino and M. J. Colmenero-Ruiz, "Emotional Intelligence in Secondary Education Students in Multicultural Contexts," Electronic Journal of Research in Educational Psychology, vol. 12, no. 2, pp. 325-342, 2014.

[35] K. Yilmaz, "the Cognitive Perspective on Learning: Its Theoretical Underpinnings and Implications for Classroom Practice," The Clearing Home: A Journal of Education Strategies, Issues, and Ideas, vol. 84, no. 5, pp. 204-212, 2011.

[36] S. Arslan and M. F. Yigit, "Investigation of the Impact of Emotional Intelligence Efficacy on Teachers' Multicultural Attitudes," Journal of Education and Practice, vol. 7, no. 11, pp. 147-157, 2016.

[37] M. S. Noemy, R. Inés G., I. G. Cristina, and A. P. Patricia, "Exploring Academic Performance: Looking beyond Numerical Grades," Universal Journal of Educational
Research, vol. 5, no. 7, pp. 1105-1112, 2017, doi:10.13189/ujer.2017.050703.

[38] H. Gardner, Kecerdasan Majemuk. Batam, Indonesia: Interaksara, 2003.

[39] D. Goleman, Emotional Intelligence: Kecerdasan Emosional (Mengapa EQ Lebih penting daripada IQ). Jakarta: Gramedia Pustaka Utama, 2002.

[40] J. D. Mayer, P. Salovey, D. Caruso, and L. Cherkasskiy, Emotional Intelligence: The Cambridge Handbook of Intelligence. New York: Cambridge, 2011.

[41] I. Sural, "21st Century Skill Level of Teacher Candidates," European Journal of Education Studies, vol. 3, no. 8, 2017.

[42] L. Baloche and C. M. Baloche, "Cooperative Learning: Exploring Challenges, Crafting Innovations," Journal of Education Learning for Teaching, vol. 43, no. 3, pp. 274 283, 2017, https://doi.org/https://doi.org/10.1080/02607476 .2017 .1319513

[43] F. H. Adams, "Using Jigsaw Technique as An Effective Way of Promoting Co-operative Learning among Primary Six Pupils in Fijai," International Journal of Education and Practice, vol. 1, no. 6, 2013.

[44] R. M. Gillies and M. Boyle, "Teachers' Reflection Cooperative Learning: Issues in Implementation," Teaching and Teacher Education, vol. 26, no. 4, pp. 933-940, 2010.

[45] A. Saad, "Students' Computational Thinking Skill through Cooperative Learning Based on Hands-on, Inquiry-based, and Student-centric Learning Approaches," Universal Journal of Educational Research, vol. 8, no. 1, pp. 290-296, 2020, 10.13189/ujer.2020.080135.

[46] R. Heale and A. Twycross, "Validity \& Reliability in Quantitative Sudies," Evidence-Based Nursing, vol. 18, no. 3, pp. 66-67, 2015.

[47] S. Sugiyono, Metode Penelitian dan Pengembangan (Research \& Development) untik Bidang Pendidikan, Manajemen, Sosial, dan Teknik. Bandung, Indonesia: Alfabeta, 2017.

[48] H. Helaluddin and H. Wijaya, Analisis Data Kualitatif: Sebuah Tinjauan Teori \& Praktik. Makassar: Sekolah Tinggi Filsafat Jaffray, 2019.

[49] Sugiyono, Metode Penelitian Pendidikan: Pendekatan Kuantitatif, Kualitatif, dan $R \& D$. Bandung, Indonesia: Alfabeta, 2011.

[50] I. T. J. Weismann, I. Tolla, and A. Sinring, "The Development of Multicultural Based Cooperative Learning Model to Enhance The Emotional Quotient of The Students of Jaffray Theology Academy of Makassar," Social Sciences, vol. 13, no. 1, pp. 1-6, 2018,

[51] H. Wijaya and A. Arismunandar, "Pengembangan Model Pembelajaran Kooperatif Tipe STAD Berbasis Media Sosial," Jurnal Jaffray, vol. 16, no. 2, pp. 175-196, 2018, https://doi.org/https://doi.org/10.25278/jj71.v16i2.302.

[52] P. Allen, K. Bennett, and B. Heritage, "SPSS Statistics Version 22: A Practical Guide," Cengage Learning Australia, 2014. [Online]. Available: https://researchreposit ory.murdoch.edu.au/id/eprint/31055/. 20-Jun-2020] 
[53] A. M. Riege, "Validity and Reliability Tests in Case Study Research: A Literature Review with 'hands on' Applications for Each Research Phase," Qualitative Market Research: An International Journal, vol. 6, no. 2, pp. 75-86, 2003.

[54] J. M. Bland and D. G. Altman, "Statistics Notes: Cronbach's Alpha," $B M J$, vol. 314, no. 7080, p. 572, 1997, https://doi.org/https://doi.org/10.1136/bmj.314.7080.572

[55] M. Tavakol and R. Dennick, "Making Sense of Cronbach's Alpha," International Journal of Medicine Education, vol. 2, pp. 53-55, 2011. doi:10.5116/ijme.4dfb.8dfd

[56] D. G. Bonett and T. A. Wright, "Cronbach's Alpha Reliability: Interval, Estimation, Hypothesis Testing, and Sample Size Planning," Journal of Organanizational Behaiour, vol. 36, no. 1, pp. 3-15, 2015. doi:10.1002/job.1 960.

[57] M. E. O’Neill and K. Mathews, “Theory \& Methods: A Weighted Least Square Approach to Learner's Test Homogenity of Variance," Australian New Zealand Journal of Statistics, vol. 42, no. 1, pp. 81-100, 2000, https://doi.org/https://doi.org/10.1111/1467-842X.00109.

[58] H. M. Park, "Comparing Group Means: T-tests and One-way ANOVA Using Stata, SAS, R and SPSS," 2009. [Online]. Available:

https://scholarworks.iu.edu/dspace/handle/2022/19735.

[Accessed: 12-Jun-2020].

[59] B. G. Tabachnick and L. S. Fidell, Experimental designs using ANOVA. New York: Thomson/Brooks/Cole, 2007.

[60] R. V. Rohlfs and R. Nielsen, "Phylogenetic ANOVA: The Expression Variance and Evolution Model for Quantitative Trait Evolution," Systematic Biology, vol. 64, no. 5, pp. 695708, 2015,https://doi.org/https://doi.org/10.1093/sysbio/syv 042 .

[61] V. Fallah, S. Khosroabadi, and H. Usefi, "Development of Emotional Quotient and Spiritual Quotient: The Strategy of Ethics Development," International Letter of Social Humanistic Sciences, vol. 49, pp. 43-52, 2015.

[62] A. Faye, G. Kalra, R. Swamy, A. Shukla, A. Subramanyam, and R. Kamath, "Study of Emotional Intelligence and Emphaty in Medical pstgraduate," Indian Journal of Psychiatry, vol. 53, pp. 140-144, 2011.

[63] D. Nuharmara, "Pengutamaan Dimensi Karakter dalam Pendidikan Agama Kristen," Jurnal Jaffray, vol. 16, no. 1, pp. 93-114, 2018, doi:10.25278/jj71.v6il.278.

[64] B. S. Sidjabat, "Kerangka Kurikulum Pendidikan Agama Kristen Berbasis Karakter di Perguruan Tinggi," Jurnal Jaffray, vol. 17, no. 1, pp. 73-90, 2019, doi:10.25278/jj71.v17il.314.

[65] S. Sahiu and H. Wijaya, "Hubungan Motivasi Belajar Ekstrinsik terhadap Hasil Belajar Psikomotorik pada Mata Pelajaran Agama Kristen Kelas V di SD Zion Makassar," Jurnal Jaffray, vol. 15, no. 2, p. 231, 2017, doi:10.25278/jj71.v15i2.262.

[66] P. C. D. Maiaweng, "Korelasi Harga Diri dan Penerimaan Sosial terhadap Kepribadian yang Sehat pada Mahasiswa STT Jaffray Makassar," Jurnal Jaffray, vol. 9, no. 1, pp. 124, 2011
[67] M. Astika and S. S. Bunga, "Hubungan Kompetensi Sosial Guru Kristen terhadap Perkembangan Karakter Siswa: Tantangan Pendidikan Kristen dalam Mencerdaskan Youth Generation," Jurnal Jaffray, vol. 14, no. 1, pp. 63-76, 2016.

[68] T. Sutarso, L. K. Baggert, P. Sutarso, and M. Tapia, "Effect of Gender and GPA on Emotional Intelligence," in The Annual Meeting of The Mid-South Educational Research Association, 1996.

[69] L. K. Baggert, P. Sutarso, and M. Tapia, Emotional Intelligence Test. Tuscaloosa, AL, 1996.

[70] M. Bernet, "Emotional Intelligence: Components and Correlates," in The Annual Meeting of The American Psychological Association, 1996.

[71] H. Jorfi, H. F. B. Yacco, and I. M. Shah, "Role of Gender in Emotional Intelligence: Relationship among Emotional Intelligence, Communication, Effectiveness and Job Satisfaction," International Journal of Management, vol. 29, no. 4, pp. 590-598, 2012.

[72] K. Rutkowska and J. Bergier, "Psychological Gender and Emotional Intelligence inYouth Female Soccer Players," Journal of Human Kinetics, vol. 47, no. 1, pp. 285-291, 2015, doi:10.1515/hukin-2015-0084.

[73] H. B. Reiff, N. M. Hatzes, M. H. Bramel, and T. Gibbon, "The Relation of LD and Gender with Emotional Intelligence in College Students," Journal of Learning Disability, vol. 34, no. 1, pp. 66-78, 2001, doi:10.1177/002221940103400106

[74] B. Mandell and S. Pherwani, "Relationship between Emotional Intelligence and Transformational Leadership Style: A Gender Comparison," Journal of Business and Psychology, vol. 17, no. 3, pp. 387-404, 2003, doi:10.1023/A:1022816409059

[75] M. Hen and M. Goroshit, "Academic Procrastination, Emotional Intelligence, Academic Self-efficacy, and GPA: A Comparison between Students with and without Learning Disabilities," Journal of Learning Disability, vol. 47, no. 2, pp. 116-124, 2014, doi:10.1177/0022219412439325.

[76] M. Tapia, "Measuring Emotional Intelligence,' Psychological Report, vol. 88, no. 2, pp. 353-364, 2001.

[77] S. W. Hystad, J. Eid, M. Tapia, A. L. Hansen, and M. D. Matthews, "An Exploratory Study of Differences in Emotional Intelligence in U.S. and Norwegian Undergraduate Students," Psychological Report, vol. 107, no. 3, pp. 891-898, 2010, doi:10.2466/04.09.17.PR0.107.6. 891-898.

[78] B. H. Johnsen, "Cultural Differences in Emotional Intelligence among Top Officers on Board Merchant Ships," International Maritime Health, vol. 63, no. 2, 2012.

[79] K. A. Crowne, "Cultural Exposure, Emotional Intelligence, and Cultural Intelligence: An Exploratory Study," International Journal of Cross Cultural Management, vol. 13, no. 1, pp. 5-22, 2013, doi:10.1177/1470595812452633.

[80] D. Chrobot-Mason and J. B. Leslie, "The Role of Multicultural Competence and Emotional Intelligence in Managing Diversity," The Psychologist-Manager Journal, vol. 15, no. 4, pp. 219-236, 2012, doi:10.1080/10887156.2 012.730442 . 